\title{
Spatial changes in the vertical distribution of calanoid copepods down to great depths in the North Pacific
}

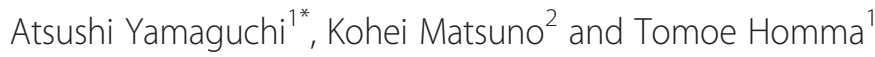

\begin{abstract}
Background: Despite its ecological importance, little information is available regarding the spatial and vertical changes in the calanoid copepod community over large geographical regions. This study investigated the spatial and vertical patterns in calanoid copepod abundance and community structure using zooplankton samples collected between depths of 0 and 2,615 $\mathrm{m}$ across the North Pacific from $0^{\circ}$ to $56^{\circ} \mathrm{N}$.

Results: A total of 211 calanoid copepod species belonging to 66 genera and 24 families were identified. Calanoid copepod abundance decreased with increasing depth, and few latitudinal differences were detected. Across the entire region, species diversity peaked near 500 to $2,000 \mathrm{~m}$ in depth. The calanoid copepod community was separated into seven groups with distinct spatial and vertical distributions. For all groups, the number of species was low (28 to 37 species) in the subarctic region (north of $40^{\circ} \mathrm{N}$ ) and high (116 to 121 species) in the subtropical-tropical region. The deepest group in the subtropical-tropical region was composed of cosmopolitan species, and this group was also observed in deep water in the subarctic region.

Conclusions: In deep water, most of the calanoid copepod community consisted of cosmopolitan species, while an endemic community was observed in the subarctic region. Because the food of deep-sea calanoid copepods originates from the surface layer, sufficient and excess flux in the eutrophic subarctic region may be responsible for maintaining the endemic species in the region.
\end{abstract}

Keywords: Zooplankton; Calanoid copepods; Community structure; Diversity; Deep-sea; North Pacific

\section{Background}

Calanoid copepods are the dominant component of the zooplankton biomass throughout the water column in the North Pacific. They consume much of the primary production and are an important link to higher trophic levels; thus, they have an important role in energy transport in marine ecosystems. Calanoid copepods are also an important component of the 'biological pump', and they transport organic matter to the deep ocean in egested fecal pellets and through diel and seasonal vertical migration (Longhurst 1991; Hernández-León and Ikeda 2005; Kobari et al. 2008b). Because calanoid copepods are the major prey of meso- and bathypelagic fishes (Merrett and Roe 1974; Hopkins and Sutton 1998; Moku

\footnotetext{
* Correspondence: a-yama@fish.hokudai.ac.jp

'Laboratory of Marine Biology, Graduate School of Fisheries Science,

Hokkaido University, 3-1-1 Minatomachi, Hakodate, Hokkaido 041-8611, Japan

Full list of author information is available at the end of the article
}

et al. 2000), it is important to clarify the calanoid copepod community structure at depth to better understand marine ecosystems.

Most studies on the community structure of calanoid copepods at great depths have collected samples using plankton nets (cf. Vinogradov 1968). Examples include studies in the Arctic Ocean (Kosobokova and Hirche 2000; Auel and Hagen 2002), Greenland Sea (Richter 1994), Bering Sea (Homma and Yamaguchi 2010), Atlantic Ocean (Roe 1972; Koppelmann and Weikert 1999), subarctic Pacific (Vinogradov 1962; Arashkevich 1972; Yamaguchi et al. 2002; Steinberg et al. 2008), Mediterranean Sea (Scotto di Calro et al. 1984; Weikert and Trinkaus 1990; Koppelmann and Weikert 2007), Arabian Sea (Madhupratap and Haridas 1990; Fabian et al. 2005; Koppelmann and Weikert 2005; Wishner et al. 2008), Red Sea (Weikert 1982; Weikert and Koppelmann 1993), and the Antarctic Ocean (Schnack-Schiel et al. 
2008). Most of these studies examined biomass, which is easy to measure, but few have identified and evaluated specimens down to species level. Furthermore, few studies have examined the abundance, species diversity, and community structure of calanoid copepods, and most that did were limited to a narrow geographical range. Throughout most of the North Pacific, little is known about the community structure throughout the water column.

During 1965 to 1967, detailed stratified zooplankton samplings from the surface to the deep sea (maximum depth 2,615 m) were made across the North Pacific $\left(0^{\circ}\right.$ to $\left.56^{\circ} \mathrm{N}\right)$, and the collected calanoid copepods were identified to the species level. In this study, we analyzed the calanoid copepod community down to great depths across the entire North Pacific. Based on this analysis, we discuss what determines the structure of calanoid copepod communities across the North Pacific.

\section{Methods}

\section{Field sampling and data gathering}

Field sampling was conducted at 12 stations between the equator and $56^{\circ} \mathrm{N}$ in the Bering Sea and Pacific Ocean during cruises of the T.S. Oshoro Maru and R.V. Hakuho Maru from 1965 to 1967 (Figure 1). Samples were collected simultaneously from six or seven discrete depths between 0 and 2,615 $\mathrm{m}$ by horizontal tows of 3 to 6 Motoda (MTD) horizontal closing nets (mesh size $350 \mu \mathrm{m}$, mouth diameter $56 \mathrm{~cm}$; Motoda
1971) (Table 1). The volume of filtered water was calculated assuming a filtering rate of 0.6 (Motoda 1971). After collection, zooplankton samples were preserved in $10 \%$ borax-buffered formalin-seawater. In the terrestrial laboratory, $1 / 32$ to $1 / 2$ aliquot subsamples were examined under microscope to identify the calanoid copepods. Although the samplings were conducted at both day and night, the day-night differences are expected to be smaller than the differences due to the large geographical $\left(0^{\circ}\right.$ to $\left.56^{\circ} \mathrm{N}\right)$ and vertical $(0$ to $2,615 \mathrm{~m}$ ) ranges in this study.

Water temperature and salinity were measured using a reversing thermometer and an inductive salinometer, respectively. Data collected by the T.S. Oshoro Maru were cited from 'Data Record of Oceanographic Observations and Exploratory Fishing' (Hokkaido University 1967), and those from the R.V. Hakuho Maru were provided by the Center for Cruise Coordination, Atmosphere and Ocean Research Institute, the University of Tokyo.

\section{Data analysis}

The species diversity index $\left(H^{\prime}\right)$ (Shannon and Weaver 1949) for calanoid copepods was calculated as:

$$
\mathrm{H}^{\prime}=-\sum n / N i \ln n / N i
$$

where $n$ is the abundance (individuals (inds.) $\mathrm{m}^{-3}$ ) of each calanoid species at the $i$ th layer, and $N i$ is the total abundance of calanoid copepods in the $i$ th layer. This

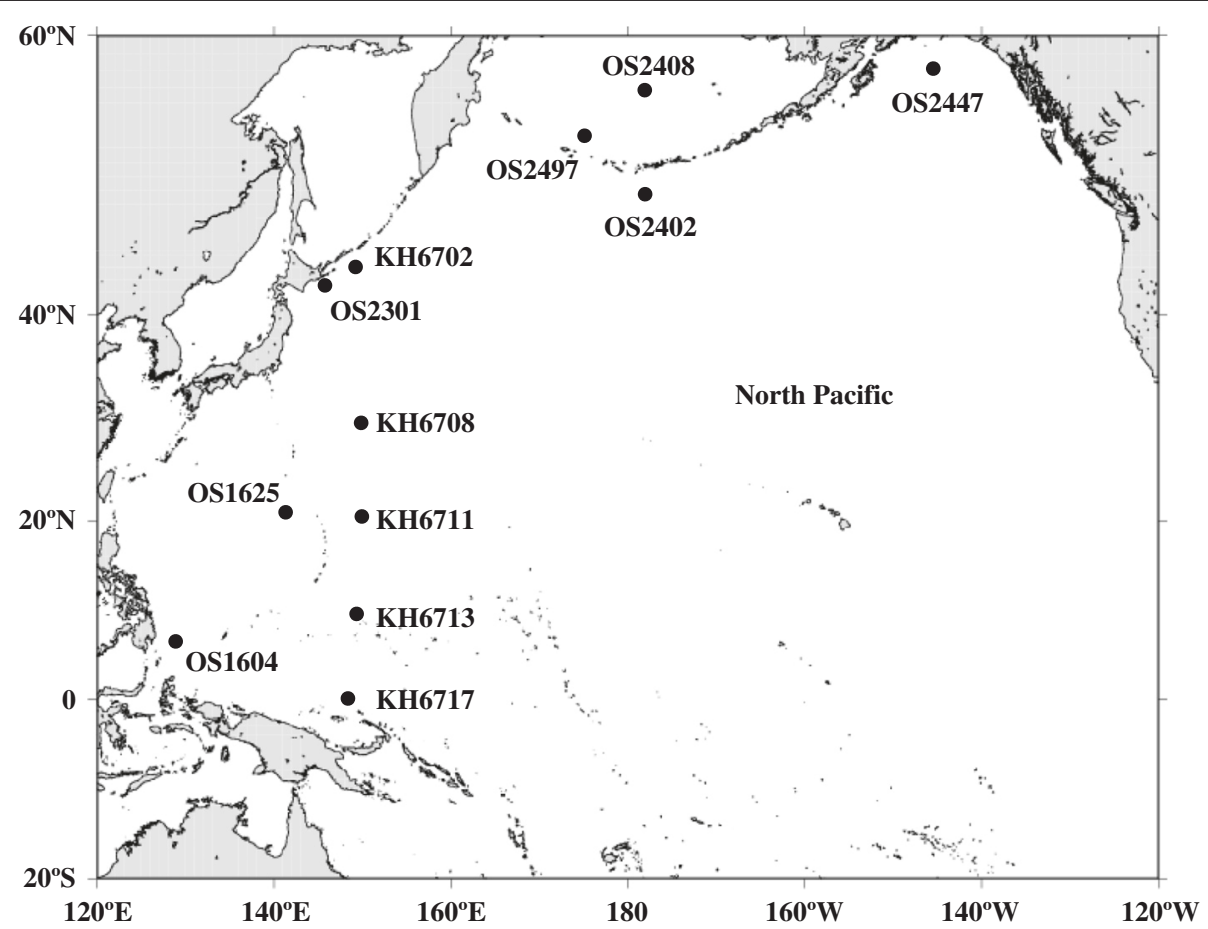

Figure 1 Locations of sampling stations in the Bering Sea and Pacific Ocean. 
Table 1 Zooplankton sampling data used in the present analyses

\begin{tabular}{|c|c|c|c|c|c|}
\hline Area & Station & Position & Sampling date & Local time & Sampled depth (m) \\
\hline \multirow[t]{3}{*}{ Bering Sea } & OS2408 & $56^{\circ} 00^{\prime} \mathrm{N} 178^{\circ} 00^{\prime} \mathrm{W}$ & 14 June 1967 & 08:54 to $09: 53$ & $0,130,270,610,983,1,285$ \\
\hline & OS2497 & $53^{\circ} 08^{\prime} \mathrm{N} 175^{\circ} 02^{\prime} \mathrm{E}$ & 20 June 1967 & $15: 42$ to $18: 24$ & $0,40,105167,277,555,1,110$ \\
\hline & & $53^{\circ} 08^{\prime} \mathrm{N} 175^{\circ} 02^{\prime} \mathrm{E}$ & 21 June 1967 & $22: 33$ to $01: 31$ & $0,85,170,260,430,860,1,720$ \\
\hline \multirow[t]{2}{*}{ Eastern North Pacific } & OS2447 & $57^{\circ} 33^{\prime} \mathrm{N} 145^{\circ} 56^{\prime} \mathrm{W}$ & 20 August 1967 & $12: 05$ to $14: 40$ & $0,65,137,200,333,665,1,330$ \\
\hline & OS2402 & $49^{\circ} 00^{\prime} \mathrm{N} 178^{\circ} 00^{\prime} \mathrm{W}$ & 10 June 1967 & $22: 06$ to $23: 39$ & $0,87,177,355,432,800$ \\
\hline \multirow[t]{11}{*}{ Western North Pacific } & KH6702 & $43^{\circ} 47^{\prime} \mathrm{N} 149^{\circ} 55^{\prime} \mathrm{E}$ & 6 December 1967 & $18: 43$ to $22: 53$ & $0,435,873,1,360,1,745,2,180,2,615$ \\
\hline & OS2301 & $42^{\circ} 00^{\prime} \mathrm{N} 146^{\circ} 00^{\prime} \mathrm{E}$ & 23 April 1967 & $12: 06$ to $13: 61$ & $7,60,120,180,240,310,360$ \\
\hline & & $42^{\circ} 00^{\prime} \mathrm{N} 146^{\circ} 00^{\prime} \mathrm{E}$ & 23 April 1967 & $22: 12$ to $23: 36$ & $7,58,117,175,233,290,345$ \\
\hline & KH6708 & $29^{\circ} 57^{\prime} \mathrm{N} 150^{\circ} 06^{\prime} \mathrm{E}$ & 13 December 1967 & 12:06 to $13: 61$ & $0,83,168,392,730,1,670,2,500$ \\
\hline & & $29^{\circ} 57^{\prime} \mathrm{N} 150^{\circ} 06^{\prime} \mathrm{E}$ & 13 December 1967 & $22: 12$ to $23: 36$ & $0,83,168,392,860,1,170,2,500$ \\
\hline & OS1625 & $20^{\circ} 47^{\prime} \mathrm{N} 141^{\circ} 45^{\prime} \mathrm{E}$ & 17 January 1966 & $09: 50$ to $13: 49$ & $7,80,153,375,740,1,475,2,200$ \\
\hline & KH6711 & $20^{\circ} 04^{\prime} \mathrm{N} 150^{\circ} 07^{\prime} \mathrm{E}$ & 17 December 1967 & 08:27 to $11: 05$ & $0,75,152,380,583,835,1,140$ \\
\hline & KH6713 & $09^{\circ} 53^{\prime} \mathrm{N} 149^{\circ} 51^{\prime} \mathrm{E}$ & 22 December 1967 & $09: 26$ to $13: 35$ & $0,65,122,317,637,1,275,1,910$ \\
\hline & & $09^{\circ} 53^{\prime} \mathrm{N} 149^{\circ} 51^{\prime} \mathrm{E}$ & 22 December 1967 & $23: 45$ to $04: 05$ & $0,80,140,347,685,2,080$ \\
\hline & OS1604 & $06^{\circ} 52^{\prime} \mathrm{N} 129^{\circ} 24^{\prime} \mathrm{E}$ & 4 December 1965 & $10: 38$ to $19: 65$ & $9,47,85,383,755,1,500$ \\
\hline & KH6717 & $0^{\circ} 02^{\prime} \mathrm{S} 148^{\circ} 52^{\prime} \mathrm{E}$ & 26 December 1967 & $18: 40$ to $20: 40$ & $0,50,105,258,518,1,035,1,555$ \\
\hline
\end{tabular}

All samples were collected with horizontal tows of Motoda horizontal closing nets (Motoda 1971).

diversity is an index of species richness, which includes qualitative evaluation. The value of the index increases when numerous species occur evenly and decreases when a few species dominate.

A Q-mode analysis, which evaluates the similarity between samples (Chiba et al. 2001), was also performed. For the $Q$-mode analysis, abundance data $\left(X\right.$ : inds. $\left.\mathrm{m}^{-3}\right)$ were first $\log$ transformed $\left(\log _{10}[X+1]\right)$. A dissimilarity matrix between each sample was constructed based on the differences in species composition using the BrayCurtis index (Bray and Curtis 1957). The matrix was analyzed by cluster analysis coupled with the unweighted pair-group method using arithmetic means to classify the samples into several groups with similar community compositions. To minimize the effect of minor species, data from only the 58 most dominant species (i.e., those that composed $>10 \%$ in total abundance in any sampling layer) were utilized (Table 2). The computer software package BIOSTAT II was employed for this analysis. To verify whether the similarity matrix reflected differences in species composition between groups, each sample was plotted on a two-dimensional map by nonmetric multi-dimensional scaling (NMDS) methods. A close distribution in the NMDS plots indicates a similar community structure. We also conducted a multiple regression analysis to clarify which environmental variables (depth, latitude, and longitude) had a significant relationship with the NMDS plot of the calanoid copepod community. To determine the indicator species for each group, a one-way ANOVA and Fisher's protected least significant difference (PLSD) test were applied to the calanoid copepod abundance data.

\section{Results \\ Hydrography}

At the sampling stations, the surface temperature ranged from $6.0^{\circ} \mathrm{C}$ to $29.7^{\circ} \mathrm{C}$, and salinity ranged from 32.4 to 35.0 (Figure 2). The study area was classified into three domains based on the locations of the subarctic front (where a $4^{\circ} \mathrm{C}$ vertical isotherm occurred below $100 \mathrm{~m}$ ) and the subarctic boundary (where a 34.0 isohaline is stretched vertically). The subarctic domain occurred north of the subarctic front, the transition domain occurred between the subarctic front and the subarctic boundary, and the tropical/subtropical domain occurred south of the subarctic boundary (Favorite et al. 1976; Anma et al. 1990). According to the T-S diagrams, stations located at $42^{\circ} 00^{\prime} \mathrm{N}$ to $56^{\circ} 00^{\prime} \mathrm{N}$ occurred in the subarctic domain, and stations at $0^{\circ} 02^{\prime} \mathrm{S}$ to $29^{\circ} 57^{\prime} \mathrm{N}$ occurred in the tropical/subtropical domain (Figure 2).

\section{Abundance and species diversity}

Vertical changes in abundance are shown in Figure 3a. Calanoid copepod abundance ranged from 0.072 to 591.8 inds. $\mathrm{m}^{-3}$; it was the greatest in the subarctic domain $\left(40^{\circ}\right.$ to $\left.50^{\circ} \mathrm{N}\right)$ and lowest in the tropical/subtropical domain $\left(0^{\circ}\right.$ to $\left.10^{\circ} \mathrm{N}\right)$. Calanoid copepod abundance decreased exponentially with increasing depth over the entire region (Figure 3a). 
Table 2 List of families and species of calanoid copepods identified in this study

\begin{tabular}{|c|c|c|}
\hline Acartiidae & Calanidae & Heterorhabdidae \\
\hline Acartia longiremis (Lilljeborg, 1853) & *Calanus pacificus Brodsky, 1948 & Disseta palumbii Giesbrecht, 1889 \\
\hline Acartia negligens Dana, 1849 & ${ }^{*}$ Canthocalanus pauper (Giesbrecht, 1888) & *Heterorhabdus abyssalis (Giesbrecht, 18 \\
\hline Acartia erythraea Giesbrecht, 1889 & ${ }^{*}$ Cosmocalanus darwinii (Lubbock, 1860) & Heterorhabdus clausi (Giesbrecht, 1889) \\
\hline Aetideidae & Megacalanus princeps Wolfenden, 1904 & Heterorhabdus norvegicus (Boeck, 1872) \\
\hline Aetideus armatus (Boeck, 1872) & Mesocalanus tenuicornis (Dana, 1849) & Heterorhabdus pacificus Brodsky, 1950 \\
\hline *Aetideus giesbrechti Cleve, 1904 & *Nannocalanus minor (Claus, 1863) & Heterorhabdus papilliger (Claus, 1863) \\
\hline Chiridius poppei Giesbrecht, 1893 & *Neocalanus cristatus (Krøyer, 1848) & Heterorhabdus spinifrons (Claus, 1863) \\
\hline${ }^{*}$ Chiridius sp. & *Neocalanus flemingeri Miller, 1988 & *Heterorhabdus tanneri (Giesbrecht, 189 \\
\hline Chirundina streetsii Giesbrecht, 1895 & *Neocalanus gracilis (Dana, 1852) & Heterostylites Iongicornis (Giesbrecht, 188 \\
\hline Chirundina sp. & *Neocalanus plumchrus (Marukawa, 1921) & Heterostylites major (Dahl F., 1894) \\
\hline Euchirella bitumida With, 1915 & *Neocalanus robustior (Giesbrecht, 1888) & Paraheterorhabdus compactus (Sars G.O. \\
\hline Euchirella curticauda Giesbrecht, 1888 & *Undinula vulgaris (Dana, 1849) & Paraheterorhabdus robustus (Farran, 190 \\
\hline Euchirella messinensis (Claus, 1863) & Candaciidae & Lucicutiidae \\
\hline Euchirella pulchra (Lubbock, 1856) & Candacia armata Boeck, 1872 & Lucicutia bicornuta Wolfenden, 1905 \\
\hline Euchirella rostrata (Claus, 1866) & Candacia bipinnata (Giesbrecht, 1889) & Lucicutia clausi (Giesbrecht, 1889) \\
\hline Euchirella truncata Esterly, 1911 & *Candacia bispinosa (Claus, 1863) & *Lucicutia curta Farran, 1905 \\
\hline Euchirella venusta Giesbrecht, 1888 & ${ }^{*}$ Candacia catula (Giesbrecht, 1889) & *Lucicutia flavicornis (Claus, 1863) \\
\hline Gaetanus armiger Giesbrecht, 1888 & Candacia columbiae Campbell, 1929 & Lucicutia grandis (Giesbrecht, 1895) \\
\hline Gaetanus brachyurus Sars G.O., 1907 & Candacia curta (Dana, 1849) & Lucicutia longiserrata (Giesbrecht, 1889) \\
\hline Gaetanus brevicornis Esterly, 1906 & ${ }^{*}$ Candacia ethiopica (Dana, 1849) & Lucicutia magna Wolfenden, 1903 \\
\hline *Gaetanus brevispinus (Sars G.O., 1900) & Candacia longimana (Claus, 1863) & Lucicutia maxima Steuer, 1904 \\
\hline Gaetanus miles Giesbrecht, 1888 & Candacia simplex (Giesbrecht, 1889) & Lucicutia orientalis Brodsky, 1950 \\
\hline Gaetanus pileatus Farran, 1903 & *Candacia truncata (Dana, 1849) & *Lucicutia ovalis (Giesbrecht, 1889) \\
\hline Gaetanus tenuispinus (Sars G.O., 1900) & Centropagoidae & Lucicutia pacifica Brodsky, 1950 \\
\hline Gaetanus spp. & Centropages abdominalis Sato, 1913 & Lucicutia polaris Brodsky, 1950 \\
\hline Pseudochirella obesa Sars G.O., 1920 & Centropages bradyi Wheeler, 1900 & Lucicutia sewelli Tanaka, 1963 \\
\hline Pseudochirella obtusa (Sars G.O., 1905) & *Centropages calaninus (Dana, 1849) & Metridiidae \\
\hline Undeuchaeta intermedia Scott A., 1909 & ${ }^{*}$ Centropages elongatus Giesbrecht, 1896 & *Metridia asymmetrica Brodsky, 1950 \\
\hline Undeuchaeta major Giesbrecht, 1888 & Centropages furcatus (Dana, 1849) & *Metridia brevicauda Giesbrecht, 1889 \\
\hline Undeuchaeta plumosa (Lubbock, 1856) & Centropages gracilis (Dana, 1849) & *Metridia curticauda Giesbrecht, 1889 \\
\hline Arietellidae & *Centropages longicornis Mori, 1932 & *Metridia okhotensis Brodsky, 1950 \\
\hline Arietellus setosus Giesbrecht, 1893 & Centropages violaceus (Claus, 1863) & *Metridia ornata Brodsky, 1950 \\
\hline Arietellus simplex Sars G.O., 1905 & Clausocalanoidae & *Metridia pacifica Brodsky, 1950 \\
\hline
\end{tabular}

Pontellidae

*Calanopia minor Scott A., 1902

Labidocera acutifrons (Dana, 1849)

Labidocera detruncata (Dana, 1849)

Labidocera japonica Mori, 1935

Labidocera pavo Giesbrecht, 1889

Pontella chierchiae Giesbrecht, 1889

Pontella denticauda Scott A., 1909

Pontella securifer Brady, 1883

Pontella spinicauda Mori, 1937

*Pontellina plumata (Dana, 1849)

Rhincalanidae

*Rhincalanus nasutus Giesbrecht, 1888

*Rhincalanus rostrifrons (Dana, 1849)

Scolecitrichidae

Amallothrix curticauda (Scott A., 1909)

Amallothrix tenuiserrata (Giesbrecht, 1893)

Amallothrix valida (Farran, 1908)

Lophothrix frontalis Giesbrecht, 1895

Pseudoamallothrix inornata (Esterly, 1906)

Pseudoamallothrix ovata (Farran, 1905)

Pseudoamallothrix profunda (Brodsky, 1950)

*Racovitzanus antarcticus Giesbrecht, 1902

Racovitzanus levis Tanaka, 1961

Scaphocalanus affinis (Sars G.O., 1905)

Scaphocalanus brevicornis (Sars G.O., 1900)

Scaphocalanus echinatus (Farran, 1905)

Scaphocalanus elongatus Scott A., 1909

Scaphocalanus magnus (Scott T., 1894)

Scaphocalanus major (Scott T., 1894)

Scolecithricella bradyi (Giesbrecht, 1888)

Scolecithricella dentata (Giesbrecht, 1893)

Scolecithricella globulosa Brodsky, 1950

Scolecithricella longifurca (Giesbrecht, 1888) 
Table 2 List of families and species of calanoid copepods identified in this study (Continued)

\begin{tabular}{|c|c|c|c|}
\hline Augaptilidae & *Clausocalanus arcuicornis (Dana, 1849) & Metridia princeps Giesbrecht, 1889 & *Scolecithricella minor (Brady, 1883) \\
\hline Augaptilus lamellifer Esterly, 1911 & *Clausocalanus pergens Farran, 1926 & *Metridia similis Brodsky, 1950 & *Scolecithricella orientalis Mori, 1937 \\
\hline Augaptilus longicaudatus (Claus, 1863) & Microcalanus pusillus Sars G.O., 1903 & *Metridia venusta Giesbrecht, 1889 & Scolecithricella spinipedata Mori, 1937 \\
\hline Augaptilus spp. & Microcalanus pygmaeus (Sars G.O., 1900) & *Pleuromamma abdominalis (Lubbock, 1856) & Scolecithricella vittata (Giesbrecht, 1893) \\
\hline Centraugaptilus porcellus Johnson M.W., 1936 & *Pseudocalanus minutus (Krøyer, 1845) & *Pleuromamma gracilis Claus, 1863 & Scolecithrix danae (Lubbock, 1856) \\
\hline Centroaugaptilus sp. & Pseudocalanus newmani Frost, 1989 & Pleuromamma quadrungulata (Dahl F., 1893) & Scottocalanus longispinus Scott A., 1909 \\
\hline Euaugaptilus angustus (Sars G.O., 1905) & Eucalanidae & *Pleuromamma scutullata Brodsky, 1950 & Scottocalanus persecans (Giesbrecht, 1895) \\
\hline Euaugaptilus facilis (Farran, 1908) & *Eucalanus bungii Giesbrecht, 1893 & *Pleuromamma xiphias (Giesbrecht, 1889) & Scottocalanus securifrons (Scott T., 1894) \\
\hline Euaugaptilus gracilis (Sars G.O., 1905) & *Eucalanus californicus Johnson M.W., 1938 & Nullosetigeridae & Spinocalanidae \\
\hline Euaugaptilus gracilis (Sars G.O., 1905) & Eucalanus elongatus (Dana, 1848) & Nullosetigera bidentata (Brady, 1883) & Monacilla typica Sars G.O., 1905 \\
\hline Euaugaptilus grandicornis Sars G.O., 1920 & Pareucalanus attenuatus (Dana, 1849) & *Nullosetigera helgae (Farran, 1908) & Spinocalanus longicornis Sars G.O., 1900 \\
\hline Euaugaptilus hecticus (Giesbrecht, 1893) & *Subeucalanus crassus (Giesbrecht, 1888) & Nullosetigera impar (Farran, 1908) & Spinocalanus spp. \\
\hline Euaugaptilus hyperboreus Brodsky, 1950 & *Subeucalanus mucronatus (Giesbrecht, 1888) & Nullosetigera integer (Esterly, 1911) & Temoridae \\
\hline Euaugaptilus nodifrons (Sars G.O., 1905) & Subeucalanus subcrassus (Giesbrecht, 1888) & Paracalanidae & Temora discaudata Giesbrecht, 1889 \\
\hline Euaugaptilus pacificus Matthews, 1972 & Subeucalanus subtenuis (Giesbrecht, 1888) & Acrocalanus gibber Giesbrecht, 1888 & Temora stylifera (Dana, 1849) \\
\hline Euaugaptilus palumboi (Giesbrecht, 1889) & Euchaetidae & *Acrocalanus gracilis Giesbrecht, 1888 & Tortanidae \\
\hline Euaugaptilus propinquus Sars G.O., 1920 & Euchaeta concinna Dana, 1849 & *Acrocalanus monachus Giesbrecht, 1888 & Tortanus discaudatus (Thompson \& Scott 1897) \\
\hline Euaugaptilus squamatus (Giesbrecht, 1889) & Euchaeta indica Wolfenden, 1905 & ${ }^{*}$ Calocalanus pavo (Dana, 1852) & \\
\hline Haloptilus acutifrons (Giesbrecht, 1893) & Euchaeta longicornis Giesbrecht, 1888 & Mecynocera clausi Thompson I.C., 1888 & \\
\hline Haloptilus longicirrus Brodsky, 1950 & *Euchaeta marina (Prestandrea, 1833) & Paracalanus parvus (Claus, 1863) & \\
\hline *Haloptilus longicornis (Claus, 1863) & Euchaeta media Giesbrecht, 1888 & Phaennidae & \\
\hline Haloptilus mucronatus (Claus, 1863) & Euchaeta plana Mori, 1937 & Cephalophanes frigidus Wolfenden, 1911 & \\
\hline Haloptilus pseudooxycephalus Brodsky, 1950 & Paraeuchaeta californica (Esterly, 1906) & Cornucalanus chelifer (Thompson I.C., 1903) & \\
\hline Haloptilus sp. & *Paraeuchaeta elongata (Esterly, 1913) & Onchocalanus affinis With, 1915 & \\
\hline Bathypontiidae & Paraeuchaeta propinqua (Esterly, 1906) & Onchocalanus magnus (Wolfenden, 1906) & \\
\hline Temorites elongata (Sars G.O., 1905) & Paraeuchaeta rubra Brodsky, 1950 & Talacalanus greenii (Farran, 1905) & \\
\hline Temorites similis (Tanaka, 1965) & Paraeuchaeta tonsa (Giesbrecht, 1895) & Xanthocalanus pulcher Esterly, 1911 & \\
\hline
\end{tabular}

*Species composing $>10 \%$ of the total copepod abundance in at least one sample used for cluster and NMDS analyses (cf. Figure 4). 


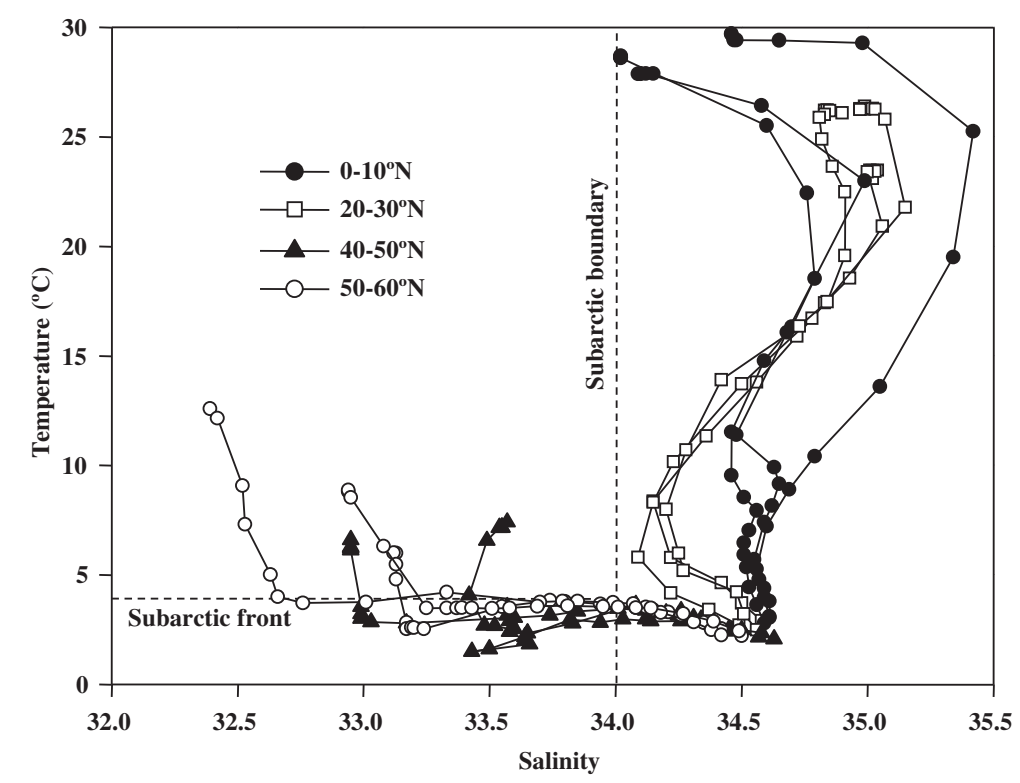

Figure 2 T-S diagram from all stations of this study in the Bering Sea and Pacific Ocean. Horizontal and vertical dashed lines indicate the locations of the subarctic front and boundary, respectively (Favorite et al. 1976; Anma et al. 1990).

Vertical changes in species diversity $\left(H^{\prime}\right)$ are shown in Figure $3 \mathrm{~b}$. $H^{\prime}$ varied from 0.04 to 3.4 ; it was low near the surface, high at depths of approximately 500 to $2,000 \mathrm{~m}$, and decreased below 2,000 $\mathrm{m}$. $H^{\prime}$ was high in the tropical/subtropical domain $\left(0^{\circ}\right.$ to $10^{\circ} \mathrm{N}, 20^{\circ}$ to $\left.30^{\circ} \mathrm{N}\right)$ and low in the subarctic domain $\left(40^{\circ}\right.$ to $60^{\circ} \mathrm{N}$; Figure $\left.3 \mathrm{~b}\right)$.

A total of 211 calanoid copepod species belonging to 66 genera and 24 families were identified (Table 2). A total of 58 species composed $>10 \%$ of the total abundance in at least one sampling layer; therefore, these species were applied in the cluster analysis. Thus, most species (153) were minor species that made up less than $10 \%$ of the total abundance in all sampling layers. The highest number of species (86 from 36 families) was observed at St. KH6708 in the subtropical domain, while the lowest number of species (20 from 14 families) was observed at St. OS2301 in the subarctic domain. This low number may have been caused by the limited sampling range $(0$ to $360 \mathrm{~m}$ ) at this station (Table 1$)$.

\section{Community structure}

Q-mode analysis classified the calanoid copepod community into seven groups (A to G) at $65 \%$ and $94 \%$ dissimilarity levels (Figure 4a). The number of samples in each group ranged from 4 to 23 . Calanoid copepod abundance was greatest in group A with $229 \pm 166$ inds. $\mathrm{m}^{-3}$ (mean $\pm \mathrm{sd}$ ), followed by group E. Species diversity $\left(H^{\prime}\right)$ was lowest in group $\mathrm{B}(1.8 \pm 0.3)$ and greatest in group $\mathrm{F}$ $(2.4 \pm 0.4)$. The number of species in each group varied between 28 and 121. Groups A to D had fewer species (28 to 37 ), and groups E to G had more (112 to 121; Figure 4a).
In the NMDS plots, the distributions of groups A to D and $E$ to $G$ were clearly separated (Figure $4 \mathrm{~b}$ ). Depth, latitude, and longitude each showed a significant relationship with calanoid copepod group ordination. Group F occurred at low latitudes, groups A and B occurred at high latitudes, and group $\mathrm{G}$ occurred at great depths.

The vertical and horizontal distributions of each group are shown in Figure 5. In the subarctic domain, group A occurred at the surface, group B occurred at 100 to $500 \mathrm{~m}$, group $\mathrm{C}$ occurred at 500 to $1,000 \mathrm{~m}$, and group D occurred at 500 to $2,250 \mathrm{~m}$. In the tropical/subtropical domain, group $\mathrm{E}$ occurred at 0 to $1,000 \mathrm{~m}$, group F occurred at 500 to $1,500 \mathrm{~m}$, and group $\mathrm{G}$ occurred at 750 to $2,615 \mathrm{~m}$. The horizontal distributions of each group were clearly separated, and the greatest discrepancy was observed between $30^{\circ}$ and $40^{\circ} \mathrm{N}$. Group G was the only group collected from deep water in both the subarctic and tropical/subtropical domains.

An ANOVA and Fisher's PLSD test were used to determine indicator species for each group (Table 3). The indicator species were as follows: Neocalanus plumchrus and Pseudocalanus minutus for group A; Eucalanus bungii, Racovitzanus antarcticus, and Scolecithricella minor for group B; Neocalanus cristatus and N. plumchrus for group C; Metridia pacifica, Metridia okhotensis, Paraeuchaeta elongata, and Pleuromamma scutullata for group D; Aetideus giesbrechti, Clausocalanus arcuicornis, Euchaeta marina, Cosmocalanus darwinii, and Undinula vulgaris for group E; Haloptilus longicornis, Metridia venusta, and Pleuromamma xiphias for group F; and Pleuromamma abdminalis and Pleuromamma gracilis for group G. 

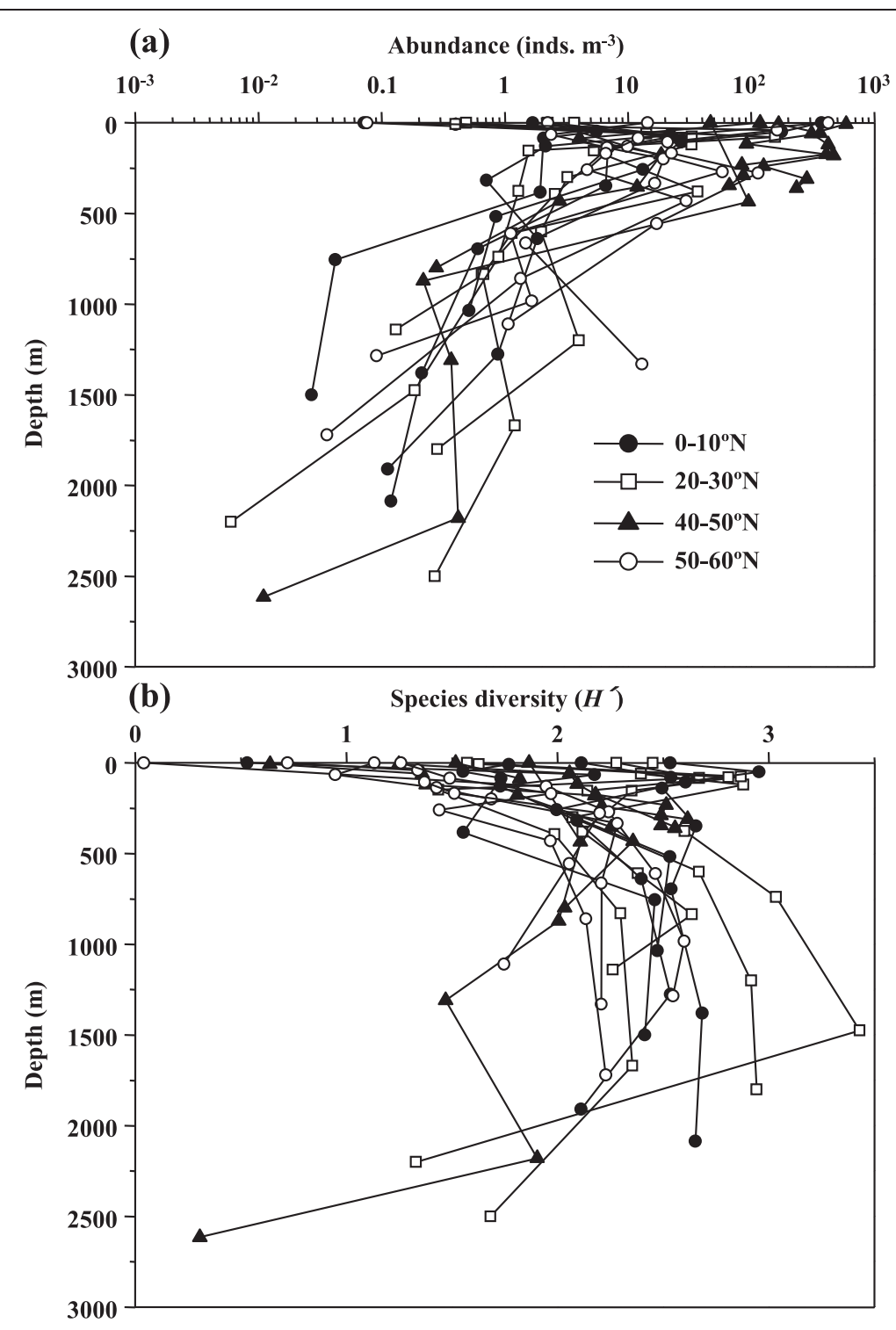

Figure 3 Vertical distribution of calanoid copepod abundance (a) and species diversity (b) in the Bering Sea and Pacific Ocean.

\section{Discussion}

\section{Abundance and species diversity}

Many studies have shown that zooplankton biomass decreases with depth, but few have examined abundance. This is partly because biomass is easier to measure and contains more useful information. Zooplankton biomass between the surface and 4,000 $\mathrm{m}$ in the North Pacific is greater in the subarctic than in the tropical/subtropical domain; in both regions, the biomass decreases with increasing depth (Vinogradov 1962). The rate of biomass decrease with increasing depth is similar in all domains, and the influence of the surface layer is known to extend over 4,000 $\mathrm{m}$ into the water column (Vinogradov 1962, 1968). Across the North Pacific, 65\% of the zooplankton biomass between depths of 0 and 4,000 m occurs at 0 to
$500 \mathrm{~m}$, and this percentage is similar through all regions because zooplankton food in the deep sea depends on sinking particles provided by the upper layer. Therefore, biomass in the deep sea is proportionate to the biomass in the surface layer (Vinogradov and Tseitlin 1983; Vinogradov 1997). Although much is known about biomass, only limited information is available on abundance and species diversity. This is partly because of the difficulty in counting and identifying zooplankton under a microscope, which requires taxonomic knowledge and a significant time investment.

The most remarkable characteristic of the vertical changes in abundance described in this study was that while latitudinal differences are common in biomass (more biomass in the subarctic and less in the subtropical, cf. 


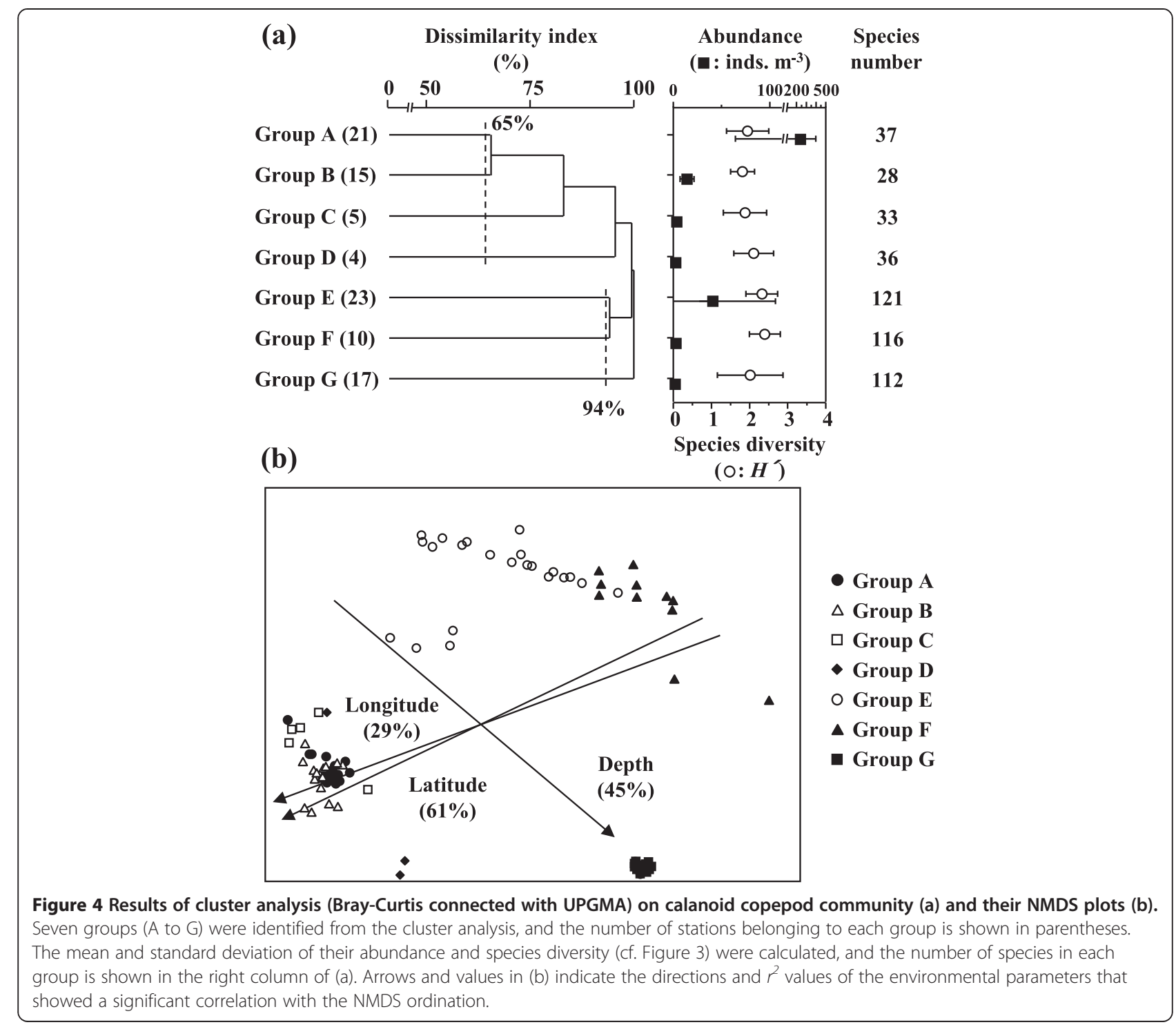

Yamaguchi et al. 2005), no differences were observed in abundance (Figure 3a). In all domains, calanoid copepods are the most abundant mesozooplankton taxa in terms of biomass (Yamaguchi et al. 2004). The latitudinal differences in zooplankton units may be caused by the latitudinal differences in individual mass. Thus, the individual size of calanoid copepods (=biomass) is expected to be larger in the subarctic domain than in the subtropical domain. In fact, Yamaguchi et al. (2004) reported that the individual size of calanoid copepods is smaller in the subtropics, while large calanoid copepods (i.e., Neocalanus spp. and Eucalanus spp.) are dominant in the subarctic, composing more than $50 \%$ of the mesozooplankton biomass in deep water.

Environmental factors that affect the vertical distribution of zooplankton abundance include the thermocline and the oxygen minimum zone (Sameoto 1986). In zooplankton biomass, a vertical minimum occurs below the thermocline throughout the year near the Kuril-Kamchatka Trench (100 to $200 \mathrm{~m}$ ) (Bogorov and Vinogradov 1955) and in the Sea of Japan (Morioka and Komaki 1978). In the oxygen minimum zone of the Red Sea, the number of common calanoid copepod species is low, while the number of specialized species is high (Weikert 1982). In the present study, the abundance and species diversity of calanoid copepods did not show a clear decrease in either the thermocline or the oxygen minimum zone (Figure 3a,b). This may be an artifact of the sampling design in this study. Because MTD nets collect samples from irregular layers during simultaneous, multi-layer, horizontal tows, the small-scale vertical distribution changes in the thermocline or oxygen minimum zone would have been difficult to evaluate.

A unique finding of this study was the vertical change in species diversity, which was low at the surface and 


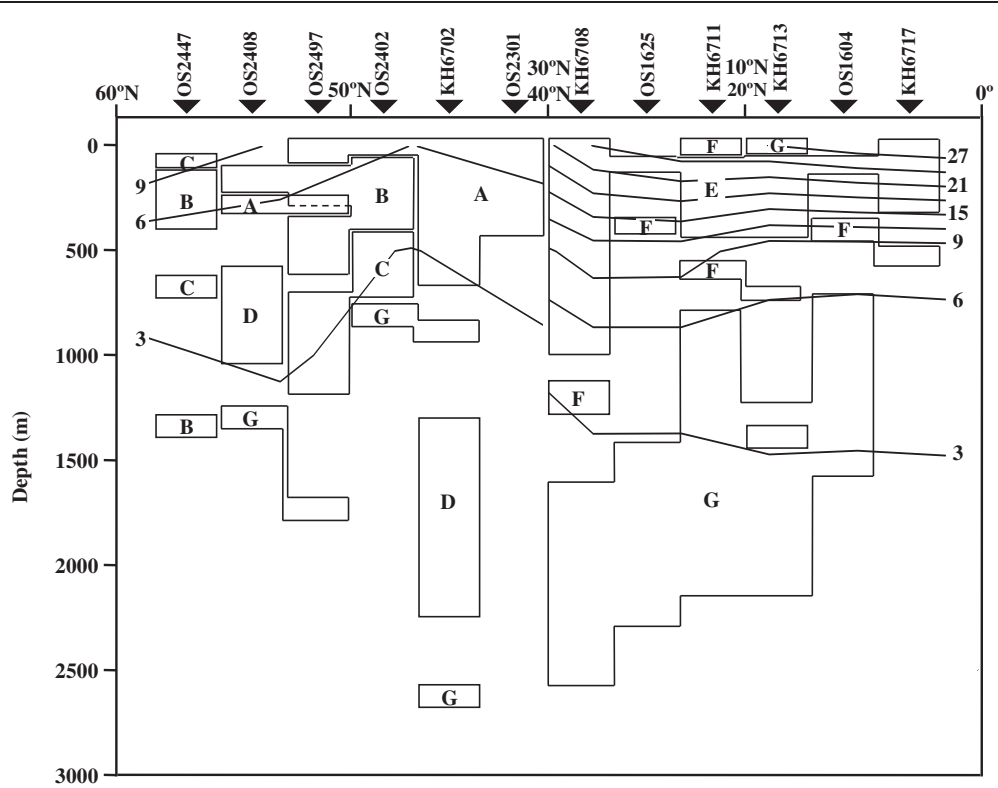

Figure 5 Horizontal and vertical distributions of seven calanoid copepod communities identified by cluster analysis (see Figure 4a). Stations are arranged from north (left) to south (right). Approximate positions of latitudes are shown in the upper margin. Temperature profiles along the latitudinal transect are superimposed.

Table 3 Mean abundance of copepods in each group identified through in-cluster analysis of the copepod community (see Figure 4a)

\begin{tabular}{|c|c|c|c|c|c|c|c|c|c|}
\hline \multirow[b]{2}{*}{ Species } & \multicolumn{7}{|c|}{ Group and abundance (log10[inds. $\left.\left.m^{-3}+1\right]\right)$} & \multirow[b]{2}{*}{$F$} & \multirow{2}{*}{$\begin{array}{l}\text { Results of } \\
\text { one-way } \\
\text { ANOVA }\end{array}$} \\
\hline & $\mathrm{A}$ & B & $\mathrm{C}$ & D & $E$ & $\mathbf{F}$ & G & & \\
\hline Aetideus giesbrechti & 0.00 & 0.00 & 0.00 & 0.00 & 0.26 & 0.10 & 0.04 & 3.37 & ** \\
\hline Clausocalanus arcuicornis & 0.00 & 0.00 & 0.100 & 0.00 & 0.67 & 0.29 & 0.04 & 16.70 & $* * *$ \\
\hline Eucalanus bungii & 1.10 & 1.68 & 1.20 & 0.51 & 0.00 & 0.00 & 0.17 & 44.00 & $* * *$ \\
\hline Euchaeta marina & 0.00 & 0.00 & 0.00 & 0.00 & 0.65 & 0.42 & 0.11 & 10.10 & $* * *$ \\
\hline Haloptilus longicornis & 0.00 & 0.00 & 0.00 & 0.00 & 0.24 & 0.40 & 0.11 & 0.01 & * \\
\hline Metridia pacifica & 1.03 & 0.84 & 0.52 & 1.52 & 0.00 & 0.00 & 0.43 & 12.10 & $* * *$ \\
\hline Metridia okhotensis & 0.33 & 0.00 & 0.00 & 0.48 & 0.00 & 0.00 & 0.06 & 4.93 & $* * *$ \\
\hline Metridia venusta & 0.00 & 0.00 & 0.00 & 0.00 & 0.00 & 0.24 & 0.21 & 3.90 & ** \\
\hline Neocalanus cristatus & 0.58 & 0.56 & 0.94 & 0.85 & 0.02 & 0.00 & 0.28 & 11.30 & $* * *$ \\
\hline Neocalanus plumchrus & 1.13 & 0.86 & 1.13 & 1.07 & 0.11 & 0.08 & 0.28 & 19.70 & $* * *$ \\
\hline Paraeuchaeta elongata & 0.01 & 0.11 & 0.16 & 0.33 & 0.00 & 0.00 & 0.16 & 2.63 & $*$ \\
\hline Pleuromamma abdminalis & 0.00 & 0.00 & 0.00 & 0.00 & 0.35 & 1.07 & 0.36 & 13.50 & $* * *$ \\
\hline Pleuromamma gracilis & 0.00 & 0.00 & 0.00 & 0.00 & 0.47 & 1.03 & 0.48 & 9.97 & $* * *$ \\
\hline Pleuromamma scutullata & 0.32 & 0.45 & 0.39 & 0.61 & 0.00 & 0.00 & 0.19 & 5.70 & $* * *$ \\
\hline Pleuromamma xiphias & 0.00 & 0.00 & 0.00 & 0.00 & 0.11 & 0.35 & 0.03 & 4.43 & $* * *$ \\
\hline Pseudocalanus minutus & 0.67 & 0.53 & 0.49 & 0.35 & 0.00 & 0.00 & 0.20 & 7.70 & $* * *$ \\
\hline Racovitzanus antarcticus & 0.19 & 0.44 & 0.00 & 0.02 & 0.00 & 0.00 & 0.20 & 3.90 & $* *$ \\
\hline Scolecithricella minor & 0.37 & 0.53 & 0.14 & 0.00 & 0.00 & 0.00 & 0.00 & 11.20 & $* * *$ \\
\hline Cosmocalanus darwinii & 0.00 & 0.00 & 0.00 & 0.00 & 0.64 & 0.08 & 0.32 & 9.20 & $* * *$ \\
\hline Undinula vulgaris & 0.00 & 0.00 & 0.00 & 0.00 & 0.36 & 0.13 & 0.04 & 5.48 & $* * *$ \\
\hline Total copepods & 2.24 & 1.13 & 0.44 & 0.26 & 1.08 & 0.36 & 0.08 & 61.4 & $* * *$ \\
\hline
\end{tabular}

${ }^{*} p<0.05,{ }^{* *} p<0.01,{ }^{* * *} p<0.001$. Groups where the significant greatest abundance was observed were italicized. 
peaked at 500 to $2,000 \mathrm{~m}$ (Figure $3 \mathrm{~b}$ ). Increases in the number of species and species diversity in the mesopelagic zone (200 to $1,000 \mathrm{~m}$ ) and bathypelagic zone (1,000 to $3,000 \mathrm{~m}$ ) have been reported in the North Atlantic (Roe 1972), the Mediterranean Sea (Scotto di Calro et al. 1984), the western North Pacific (Yamaguchi et al. 2002), and the Bering Sea (Homma and Yamaguchi 2010). This suggests that an increase in the number of calanoid copepod species in the meso- and bathypelagic zones is a common phenomenon of the ocean worldwide. The differentiation of calanoid copepod species is reported to strongly influence their feeding habits, and an increased number of species in the meso- and bathypelagic zones are reported to reflect diverse feeding modes in these zones (Ohtsuka and Nishida 1997). In fact, detritivores attached to marine snow do not occur in the surface layer but constitute more than $50 \%$ of the total calanoid copepod abundance in the meso- and bathypelagic zones of the western subarctic Pacific and Bering Seas (Yamaguchi et al. 2002; Homma and Yamaguchi 2010). Large sinking particles (e.g., marine snow and giant larvacean house) play an important role as microcosms in the deep sea. The abundance of zooplankton attached to marine snow in the deep sea is reported to be 200 times higher than those in the surrounding waters (Steinberg et al. 1994, 1998).

\section{Community structure}

In the North Pacific, calanoid copepod communities in the surface layer generally correspond to the ocean current system and can be separated into subarctic and tropical/subtropical communities. The number of species is greater in the tropical/subtropical than in the subarctic (McGowan and Walker 1979; Ohtsuka and Ueda 1999). Much is known about calanoid copepod communities in the surface layer; however, little is known about those in the deep sea. In the present study, deep-sea calanoid copepods were divided into seven groups (A to G; Figure $4 \mathrm{a}$ ), and the distribution of each group was clearly separated (Figure 5). Groups A to D occurred north of $40^{\circ} \mathrm{N}$ and consisted of a small number (28 to 37 species) of species. Groups E to G occurred mainly south of $30^{\circ} \mathrm{N}$ in the tropical/subtropical domain, and group G occurred in deep water in both the subarctic and tropical/subtropical domains where the temperature was below $3^{\circ} \mathrm{C}$ (Figure 5). Groups $\mathrm{E}$ to $\mathrm{G}$ contain a large number (116 to 121 species) of species, indicating that the number of species was high in both shallow and deep water in the trop$\mathrm{ical} /$ subtropical domain.

The wide distribution of Group $G$ indicates that this group consists of cosmopolitan species that occur widely throughout the uniform environmental condition of the deep sea (Figure 5). Concerning the regional distribution of the deep-sea calanoid copepod genus Paraeuchaeta, Park (1994) noted that the cosmopolitan species occurred widely in the oligotrophic region, while endemic species were found in the deep sea of the eutrophic region (e.g., subarctic Pacific and Antarctic). Park suggested that most food of deep-sea zooplankton sinks from the surface and that the low flux of sinking material in the oligotrophic region could maintain only cosmopolitan species; in contrast, the higher flux in the eutrophic region could sustain the endemic species (Park 1994). Group D in the deep sea of the subarctic domain consisted of endemic species in the subarctic Pacific (Table 3; M. pacifica, M. okhotensis, $P$. elongata, and $P$. scutullata) and corresponded to the endemic deep-sea species group observed in the eutrophic region (Park 1994). The uniform low temperature $\left(\leq 3^{\circ} \mathrm{C}\right)$ in the deep sea indicates that there is no barrier to the distribution of deep-sea cosmopolitan species. This is presumably why group $G$ (cosmopolitan species) was the only calanoid copepod community observed in both the subarctic and tropical/subtropical domains (Figure 5).

Some zooplankton have bipolar distributions; for instance, the chaetognath Eukrohnia hamata occurs at the surface layer at high latitudes and below 1,000 m near the equator (Pierrot-Bults and Nair 1991). For calanoid copepods, a bipolar distribution is considered to be possible for carnivorous or omnivorous species but may be difficult for herbivorous species that feed on phytoplankton in the epipelagic layer (Machida et al. 2006). In the present study, the species characterizing each group were identified (Table 3), but the limited study area (North Pacific) prevented an evaluation of bipolar distributions.

$N$. plumchrus was the only species that occurred in all groups (A to G) (Table 3). N. plumchrus is a subarctic species that occurs in the surface layer during the spring phytoplankton bloom and descends to deep water during the rest of the year (Miller and Clemons 1988; Kobari and Ikeda 2001). Various authors have reported that the diapause stages C5 and C6 of Neocalanus spp. are transported to the deep sea in the subtropical domain by the submerged Oyashio undercurrent (Omori and Tanaka 1967; Oh et al. 1991; Shimode et al. 2006; Kobari et al. 2008a). Within the tropical/subtropical community (groups E, F, and G), the order of depth distribution was $\mathrm{E}<\mathrm{F}<\mathrm{G}$, and the shallowest group (E) was also occasionally observed at 1,000 m (St. KH6708, Figure 5). Thus, the transported $N$. plumchrus might have occurred in all tropical/subtropical community groups (groups E to G). Concerning the southern limit of transported Neocalanus spp., Yamaguchi et al. (2004) reported that they occur at $30^{\circ} \mathrm{N}$, but not at $25^{\circ} \mathrm{N}$; this agrees with the southern limit of their distribution $\left(28^{\circ} \mathrm{N}\right)$ reported by Omori (1967). While Neocalanus spp. transported south of $40^{\circ} \mathrm{N}$ are important in terms of adding additional biomass to the deep-sea subtropical domain (Yamaguchi et al. 2004), this is considered to be an 
abortive transport, and they are not thought to reproduce in the subtropical domain (Oh et al. 1991).

\section{Conclusions}

In deep water, most of the calanoid copepod community consists of cosmopolitan species, while an endemic community was observed in the subarctic region. Because the food of deep-sea calanoid copepods originates on the surface layer, sufficient and excess flux in the eutrophic subarctic region may be responsible for maintaining endemic species in the region.

\section{Competing interests}

The authors declare that they have no competing interests.

\section{Authors' contributions}

AY and TH wrote the manuscript. KM participated in the design of the study and assisted with the statistical analyses. All authors read and approved the final manuscript.

\section{Acknowledgements}

We express our sincere thanks to Dr. Yasuhiro Morioka, who allowed us to use the calanoid copepod data in this study. This study was supported by a Grant-in-Aid for Scientific Research (A) 24248032 and a Grant-in-Aid for Scientific Research on Innovative Areas 24110005 from the Japan Society for the Promotion of Science (JSPS).

\section{Author details}

${ }^{1}$ Laboratory of Marine Biology, Graduate School of Fisheries Science, Hokkaido University, 3-1-1 Minatomachi, Hakodate, Hokkaido 041-8611, Japan. ${ }^{2}$ Arctic Environmental Research Centre, National Institute of Polar Research, 10-3 Midori-cho, Tachikawa, Tokyo 190-8518, Japan.

Received: 23 July 2014 Accepted: 23 December 2014

Published online: 14 January 2015

\section{References}

Anma G, Masuda K, Kobayashi G, Yamaguchi H, Meguro T, Sasaki T, Ohtani K (1990) Oceanographic structures and changes around the transition domain along 180 degree longitude, during June 1979-1988. Bull Fac Fish Hokkaido Univ 41:73-88

Arashkevich EG (1972) Vertical distribution of different trophic groups of copepods in the boreal and tropical regions of the Pacific Ocean. Oceanology 12:315-325

Auel H, Hagen W (2002) Mesozooplankton community structure, abundance and biomass in the central Arctic Ocean. Mar Biol 140:1013-1021

Bogorov V, Vinogradov ME (1955) Some essential features of zooplankton distribution in the Northwestern Pacific Ocean. Trudy Inst Okeanol Acad Nauk USSR 18:113-23 (English translation in US Fish Wildl Serv Spec Sci Rep-Fish 192:6-15, Washington 1956)

Bray JR, Curtis JT (1957) An ordination of the upland forest communities of southern Wisconsin. Ecol Monogr 27:325-349

Chiba S, Ishimaru T, Hosie GW, Fukuchi M (2001) Spatio-temporal variability of zooplankton community structure off east Antarctica (90 to $160^{\circ} \mathrm{E}$ ). Mar Ecol Prog Ser 216:95-108

Fabian H, Koppelmann R, Weikert H (2005) Full-depth zooplankton composition at two deep sites in the western and central Arabian Sea. Indian J Mar Sci 34:174-187

Favorite F, Dodimead AJ, Nasu K (1976) Oceanography of the subarctic Pacific region, 1960-71. Int North Pac Fish Comm Bull 33:1-187

Hernández-León S, Ikeda T (2005) A global assessment of mesozooplankton respiration in the ocean. J Plankton Res 27:153-158

Hokkaido University (1967) Data record of oceanographic observations and exploratory fishing No.11. Fac Fish Hokkaido Univ, Hakodate

Homma T, Yamaguchi A (2010) Vertical changes in abundance, biomass and community structure of copepods down to $3000 \mathrm{~m}$ in the southern Bering Sea. Deep-Sea Res | 57:965-977
Hopkins TL, Sutton TT (1998) Midwater fishes and shrimps as competitors and resource partitioning in low latitude oligotrophic ecosystems. Mar Ecol Prog Ser 164:37-45

Kobari T, Ikeda T (2001) Ontogenetic vertical migration and life cycle of Neocalanus plumchrus (Crustacea: Copepoda) in the Oyashio region, with notes on regional variations in body sizes. J Plankton Res 23:287-302

Kobari T, Moku M, Takahashi K (2008a) Seasonal appearance of expatriated boreal copepods in the Oyashio-Kuroshio mixed region. ICES J Mar Sci 65:469-476

Kobari T, Steinberg DK, Ueda A, Tsuda A, Silver MW, Kitamura M (2008b) Impacts of ontogenetically migrating copepods on downward carbon flux in the western subarctic Pacific Ocean. Deep-Sea Res II 55:1648-1660

Koppelmann R, Weikert H (1999) Temporal changes of deep-sea mesozooplankton abundance in the temperate NE Atlantic and estimates of the carbon budget. Mar Ecol Prog Ser 179:27-40

Koppelmann R, Weikert H (2005) Temporal and vertical distribution of two ecologically different calanoid copepods (Calanoides carinatus Krøyer 1849 and Lucicutia grandis Giesbrecht 1895) in the deep waters of the central Arabian Sea. Mar Biol 147:1173-1178

Koppelmann R, Weikert H (2007) Spatial and temporal distribution patterns of deep-sea mesozooplankton in the eastern Mediterranean- indications of a climatically induced shift? Mar Ecol 28:259-275

Kosobokova K, Hirche H-J (2000) Zooplankton distribution across the Lomonosov Ridge, Arctic Ocean: species inventory, biomass and vertical structure. Deep-Sea Res | 47:2029-2060

Longhurst AR (1991) Role of the marine biosphere in the global carbon cycle. Limnol Oceanogr 36:1507-1526

Machida RJ, Miya MU, Nishida M, Nishida S (2006) Molecular phylogeny and evolution of the pelagic copepod genus Neocalanus (Crustacea: Copepoda). Mar Biol 148:1071-1079

Madhupratap M, Haridas P (1990) Zooplankton, especially calanoid copepods, in the upper $1000 \mathrm{~m}$ of the south-east Arabian Sea. J Plankton Res 12:305-321

McGowan JA, Walker PW (1979) Structure in the copepod community of the North Pacific central gyre. Ecol Monogr 49:195-226

Merrett NR, Roe HSJ (1974) Patterns and selectivity in the feeding of certain mesopelagic fishes. Mar Biol 28:115-126

Miller CB, Clemons MJ (1988) Revised life history analysis for large grazing copepods in the subarctic Pacific Ocean. Prog Oceanogr 20:293-313

Moku M, Kawaguchi K, Watanabe H, Ohno A (2000) Feeding habits of three dominant myctophid fishes, Diaphus theta, Stenobrachius leucopsarus and S. nannochir, in the subarctic and transitional waters of the western North Pacific. Mar Ecol Prog Ser 207:129-140

Morioka Y, Komaki Y (1978) Seasonal and vertical distribution of zooplankton biomass in the Japan Sea. Bull Jpn Sea Reg Fish Res Lab 29:255-267

Motoda S (1971) Devices of simple plankton apparatus V. Bull Fac Fish Hokkaido Univ 22:101-106

Oh B-C, Terazaki M, Nemoto T (1991) Some aspects of the life history of the subarctic copepod Neocalanus cristatus (Calanoida) in Sagami Bay, central Japan. Mar Biol 111:207-212

Ohtsuka S, Nishida S (1997) Reconsideration on feeding habits of marine pelagic copepods (Crustacea) (in Japanese with English abstract). Oceanogr Jpn 6:299-320

Ohtsuka S, Ueda H (1999) Zoogeography of pelagic copepods in Japan and its adjacent waters (in Japanese with English abstract). Bull Plankton Soc Jpn 46:1-20

Omori M (1967) Calanus cristatus and submergence of the Oyashio water. Deep-Sea Res 14:525-532

Omori M, Tanaka O (1967) Distribution of some cold-water species of copepods in the Pacific water off east-central Honshu, Japan. J Oceanogr Soc Jpn 23:63-73

Park T (1994) Geographic distribution of the bathypelagic genus Paraeuchaeta (Copepoda, Calanoida). Hydrobiologia 292(293):317-332

Pierrot-Bults AG, Nair VR (1991) Distribution patterns in Chaetognatha. In: Bone Q, Kapp H, Pierrot-Bults AC (eds) The biology of chaetognaths. Oxford Univ. Press, Oxford

Richter C (1994) Regional and seasonal variability in the vertical distribution of mesozooplankton in the Greenland Sea. Ber Polarforsch 154:1-87

Roe HSJ (1972) The vertical distributions and diurnal migrations of calanoid copepods collected on the SOND cruise, 1965. I The total population and general discussion J Mar Biol Assoc UK 52:277-314

Sameoto DD (1986) Influence of the biological and physical environment on the vertical distribution of mesozooplankton and micronekton in the eastern tropical Pacific. Mar Biol 93:263-279 
Schnack-Schiel SB, Michels J, Mizdalski E, Schodlok MP, Schröder M (2008) Composition and community structure of zooplankton in the sea ice-covered western Weddell Sea in spring 2004-with emphasis on calanoid copepods. Deep-Sea Res II 55:1040-1055

Scotto di Calro B, lanora A, Fresi E, Hure J (1984) Vertical zonation patterns for Mediterranean copepods from the surface to $3000 \mathrm{~m}$ at a fixed station in the Tyrrhenian Sea. J Plankton Res 6:1031-1056

Shannon CE, Weaver W (1949) The mathematical theory of communication. The Univ, Illinois Press, Urbana

Shimode S, Toda T, Kikuchi T (2006) Spatio-temporal changes in diversity and community structure of planktonic copepods in Sagami Bay, Japan. Mar Biol 148:581-597

Steinberg DK, Silver MW, Pilskaln CH, Coale SL, Paduan JB (1994) Midwater zooplankton communities on pelagic detritus (giant larvacean houses) in Monterey Bay, California. Limnol Oceanogr 39:1606-1620

Steinberg DK, Pilskaln CH, Silver MW (1998) Contribution of zooplankton associated with detritus to sediment trap 'swimmer' carbon in Monterey Bay, California, USA. Mar Ecol Prog Ser 164:157-166

Steinberg DK, Cope JS, Wilson SE, Kobari T (2008) A comparison of mesopelagic mesozooplankton community structure in the subtropical and subarctic North Pacific Ocean. Deep-Sea Res II 55:1615-1635

Vinogradov ME (1962) Feeding of the deep-sea zooplankton. Rapp P-v Reun Cons Perm Int Exp Mer 153:114-120

Vinogradov ME (1968) Vertical distribution of the oceanic zooplankton. Academy of Science of the USSR, Institute of Oceanography (in Russian, English translation by Israel Program for Scientific Translations). Keter Press, Jerusalem

Vinogradov ME (1997) Some problems of vertical distribution of meso- and macroplankton in the ocean. Adv Mar Biol 32:1-92

Vinogradov ME, Tseitlin VB (1983) Deep-sea pelagic domain (aspects of bioenergetics). In: Rowe GT (ed) The sea vol. 8: deep-sea biology. John Wiley \& Sons, New York

Weikert H (1982) The vertical distribution of zooplankton in relation to habitat zones in the area of the Atlantis II Deep, Central Red Sea. Mar Ecol Prog Ser 8:129-143

Weikert H, Koppelmann R (1993) Vertical structural patterns of deep-living zooplankton in the NE Atlantic, the Levantine Sea and the Red Sea: a comparison. Oceanol Acta 16:163-177

Weikert H, Trinkaus S (1990) Vertical mesozooplankton abundance and distribution in the deep Eastern Mediterranean Sea SE of Crete. J Plankton Res 12:601-628

Wishner KF, Gelfman C, Gowing MM, Outram DM, Rapien M, Williams RL (2008) Vertical zonation and distributions of calanoid copepods through the lower oxycline of the Arabian Sea oxygen minimum zone. Prog Oceanogr 78:163-191

Yamaguchi A, Watanabe Y, Ishida H, Harimoto T, Furusawa K, Suzuki S, Ishizaka J, Ikeda T, Takahashi MM (2002) Community and trophic structures of pelagic copepods down to greater depths in the western subarctic Pacific (WEST-COSMIC). Deep-Sea Res I 49:1007-1025

Yamaguchi A, Watanabe Y, Ishida H, Harimoto T, Furusawa K, Suzuki S, Ishizaka J, Ikeda T, Takahashi MM (2004) Latitudinal differences in the planktonic biomass and community structure down to the greater depths in the western North Pacific. J Oceanogr 60:773-787

Yamaguchi A, Watanabe $Y$, Ishida H, Harimoto T, Maeda M, Ishizaka J, Ikeda T, Takahashi MM (2005) Biomass and chemical composition of net-plankton down to greater depths (0-5800 $\mathrm{m}$ ) in the western North Pacific Ocean. Deep-Sea Res | 52:341-353

\section{Submit your manuscript to a SpringerOpen ${ }^{\circ}$ journal and benefit from:}

- Convenient online submission

- Rigorous peer review

- Immediate publication on acceptance

- Open access: articles freely available online

- High visibility within the field

- Retaining the copyright to your article

Submit your next manuscript at springeropen.com 